\title{
Studies on Grain Yield, Physico-Chemical and Cooking Characters of Elite Rice Varieties (Oryza sativa L.) in Eastern India
}

\author{
H. N. Subudhi ${ }^{1}$, D. Swain ${ }^{1}$, Sanjukta Das ${ }^{1}$, S. G. Sharma ${ }^{1} \&$ O. N. Singh ${ }^{1}$ \\ ${ }^{1}$ Central Rice Research Institute, Cuttack, Orissa, India \\ Correspondence: H. N. Subudhi, Central Rice Research Institute, India. E-mail: \\ dr_hatanath_subudhi@yahoo.co.in
}

Received: August 20, 2012 Accepted: September 10, 2012 Online Published: November 15, 2012

doi:10.5539/jas.v4n12p269 URL: http://dx.doi.org/10.5539/jas.v4n12p269

\begin{abstract}
Forty one rice varieties of different ecologies are evaluated at Central Rice Research Institute, Cuttack to find out varieties having better quality characters and yield. It is revealed that hulling percentage is very good in all the genotypes and ranged from 71.0 (Vanaprava) to 81.0 (Ajay). The milling recovery varied from 62.0 (Vanaprava) to 76.0 (Radhi). The HRR\% varied from 43.5 (Kalyani-2) to 68.0 (Pooja). The kernel length is highest in Geetanjali (7.54) and lowest in Nuadhusara (3.88). Kernel length after cooking is very important character and varied from 7.9 (Nuakalajeera) to 12.5 (Geetanjali). Elongation ratio is highest in Nuadhusara (2.07) and Nuakalajeera (2.0) and lowest in Chandan (1.44). Volume expansion ratio is highest in Nua kalajeera (5.25), Nuadhusara (5.15) and lowest in Udaya (3.25). Amylose content is intermediate in all the tested genotypes except Heera and Vanaprava and it ranged from 22.1 (Utkalprava) to 26.1 (Vanaprava). The yield is highest in Rajlaxmi $\left(7100 \mathrm{~kg} \mathrm{ha}^{-1}\right)$ followed by Ajay $\left(6400 \mathrm{~kg} \mathrm{ha}^{-1}\right)$, Satyakrishna $\left(6300 \mathrm{~kg} \mathrm{ha}^{-1}\right)$, Vashadhan $\left(6200 \mathrm{~kg} \mathrm{ha}^{-1}\right)$ and lowest in Tara $\left(2800 \mathrm{~kg} \mathrm{ha}^{-1}\right)$.
\end{abstract}

Keywords: physical, chemical, cooking characters, grain yield, rice varieties, India

\section{Introduction}

Rice is the staple food for over half of the world population and it is ranked as the number one human food crop in world (Itani et al., 2002). More than 90\% world rice is grown and consumed in Asia (Tyagi et al., 2004), where as $60 \%$ calories are consumed by 3 billion Asians. India is the second most populous nation, stands first in areas, second in production followed and preceded by China. Rice occupies a pivotal place in Indian food and livelihood security system. It provides about $75 \%$ of the average calories and $55 \%$ of the protein in the average daily diet of the people (Anonymous, 2002). In India, rice occupies $44.6 \mathrm{mha}$. Grain quality in rice is determined by the factors such as grain appearance, nutritional value, cooking and eating quality (Juliano et al., 1990). The nutritional values and processing properties are very important for overall health of the people and commercial purposes including economy of the rice growers. Quality is very important determinant of market price, consumers acceptance and end users. Consumers preference is based on appearance, milling and cooking processes, grain shape and size.

Good grain quality fetches higher price for the farmers. Demand for better grain quality is increasing in the economically developed and developing countries. Earlier emphasis was given for high yield and insect/disease resistance during varietal development. But now, quality is the important breeding objective in rice breeding programme in all rice growing countries. As unattractive grain character and unsatisfactory cooking quality hampers the acceptance and spread of modern variety, quality improvement receives special emphasis since last one decade. Till today, India has released 705 released rice variety with out testing for quality characters (Thongbam et al., 2010). Now quality characters are considered during variety development and release. So the breeders have given due emphasis for quality characters. Sobha et al. (2008) studied the quality characters of 78 released varieties for India. There after, the quality characters of 28 rice land races of Assam were studied (Das \& Borah, 2008). Realizing the importance, Bhonsle and Sellapan (2010) evaluated 22 traditional rice varieties of Goa for their physico-chemical characters. Fifty six high yielding varieties were also studied for quality characters in Kerala (Vanaja \& Babu, 2006). Eleven rice genotypes of Faizabad were evaluated for quality characters (Srivastava et al., 2012). Keeping this in view, 41 promising rice varieties of eastern India were 
evaluated for quality characters to find out better genotypes to be used as donors in breeding programme and popularized among the farmers.

\section{Materials and Methods}

\subsection{Experimental Location and Materials}

This experiment was conducted in 2008 and 2009 wet seasons at the experimental farm of Central Rice Research Institute, Cuttack. 41 high yielding rice varieties viz. 5 upland varieties (Kalinga-3, Vandana, Vanaprava, Heera, Kalyni-2), 15 irrigated varieties (Kshira, Indira, Shaktiman, Radhi, Tara, Tapaswini, Saket-4, Ratna, Udaya, Supriya, Naveen, Samalei, Chandan, Chandrama, Satyakrishna), 13 lowland varieties (CR1014, Pooja, Padmini, Utkalprava, Lunishree, Panidhan, Gayatri, Tulsi, Durga, Sarala, Savitri, Varshadhan, Hanseswari), 4 aromatic varieties (Geetanjali, Ketekijoha, Nuadhusara, Nuakalajeera), 2 quality rice varieties (Lalat, BPT-5204) and 2 hybrids (Ajay, Rajlaxmi) developed for the Orissa state were transplanted with BPT-5204 as local check (Table 2). 25 days old seedlings were transplanted in Randomized Block Design with three replications and spacing was $15 \times 20 \mathrm{~cm}$. The recommended dose of N: P: K (80:40:40) was applied.

\subsection{Methods}

After three months of harvest, samples were cleaned thoroughly using winnower to remove the chaff and other foreign matters and dried in hot air oven up to $12-14 \%$ moisture content. Analysis of all traits were done in two replications.

\subsubsection{Physical Properties}

Kernel length, kernel breadth and length breadth ratio were measured by dial micrometer (Ramiah, 1969). Hulling and milling were done by using standard rice huller (Satake Thuzja) and rice polisher (Satake TMO5A) respectively. After cleaning and weighing the dehusked kernel (brown rice) hulling \% was calculated. Dehusked kernels were polished to remove bran and milling percent was calculated.

\subsubsection{Chemical Properties}

Alkali spreading value was analyzed (Little et al., 1958). Amylose content was analyzed following Juliano (1971).

\subsubsection{Cooking Characters}

Water uptake and volume expansion ratio were calculated (Anonymous, 2004; Beachell \& Stansel, 1963). Similarly kernel length after cooking and elongation ratio were measured following Azeez and Shafi (1966). The grain yield was recorded on plot basis and converted to per hectare. All the pooled data were analyzed (K. A. Gomez \& A. A. Gomez, 1984).

\section{Results}

\subsection{Milling Characters}

The analysis of variance showed highly significant value for each characters (Table 1).

Table 1: Analysis of variance for 12 quality characters

\begin{tabular}{cccc}
\hline \multicolumn{4}{c}{ Source of variation } \\
\hline Characters & Replication & Genotypes & Error \\
Hulling (\%) & 0.923 & $8.108^{* *}$ & 0.986 \\
Milling (\%) & 9.155 & $20.240^{* *}$ & 10.513 \\
HRR (\%) & 0.901 & $83.528^{* *}$ & 5.051 \\
KL (mm) & 0.044 & $1.257^{* *}$ & 0.017 \\
KB (mm) & 0.002 & $0.129^{* *}$ & 0.002 \\
L/B & 0.008 & $0.537^{* *}$ & 0.008 \\
Water uptake & 82.0 & $6676.82^{* *}$ & 350.75 \\
ASV & 0.076 & $2.712^{* *}$ & 0.018 \\
KLAC & 0.102 & $2.310^{* *}$ & 0.039 \\
VER & 0.206 & $0.379^{* *}$ & 0.076 \\
ER & 0.002 & $0.036^{* *}$ & 0.001 \\
AC (\%) & 0.110 & $2.173^{* *}$ & 0.289 \\
\hline
\end{tabular}

Note: *, ${ }^{*}$ significant at $5 \%$ and $1 \%$ level respectively. 
The dehulling of rice is one of the important post harvest processes. If the hulling percentage is high, then the recovery of rice also increase. The hulling (\%) varied from 71.0 (Vanaprava) to 81.0 (Ajay). The varieties viz., Radhi, Indira, Tapaswini Naveen, Lunishree, Gayatri, Durga, Geetanjali, Lalat etc are having $>80.0 \%$ hulling. The lowest hulling percentage was observed in Vanaprava (71.0) and Kalinga-3 (72.5).

Milling out turn is the measure of rough rice recovery during milling. It is one of the important properties to the millers. The rice millers prefer varieties with high milling and head rice recovery, where as consumers preference depend on cooking and eating qualities (Merca \& Juliano, 1981). The milling recovery is lowest in Vanaprava (62.0) and highest in Radhi (76.0). Out of 41 varieties, 29 varieties showed high milling out turn i.e. $>70 \%$. Most of the upland varieties showed low milling out turn.

Head rice recovery is the proportion of whole grains in milled rice. It varies depending on the variety, grain type, cultural practices and drying condition (Asish et al., 2006). More emphasis should be given to head rice recovery than to total rice yield since it is more important commercially and it is easier to improve (Jenning et al., 1979). $\mathrm{HRR} \%$ is a heritable trait although environmental factors and post harvest handling are known to break the grain during milling (Fan et al., 2000). HRR\% varied from 43.5 (Kalyani-2) to 68.0 (Pooja). Out of 41 varieties, 22 varieties are having better HRR\% i.e $>60.0$. The upland varieties are having low head rice recovery i.e $<60.0 \%$. The scented and hybrid varieties are also having very good head rice recovery percent.

\subsection{Physical Characters}

Grain shape, size and appearance are very important characters and determine the consumers acceptability. On the basis of average length and breadth of the kernel, these were classified in to different shape and size (IRRI,1996). The kernel length is highest in Geetanjali (7.54) followed by Rajlaxmi (7.45), Ajay (7.25), Lunishree (7.1), Samalei (6.7), Kalyni-2 (6.6) and Vanaprava (6.6) and lowest in Nuadhusara (3.88) followed by Nuakalajeera (3.92).

The kernel breadth varied from 1.74 (Satyakrishana) to Hanseswari (2.68). Depending on L/B ratio, 13 varieties viz., Saket-4, Ratna, Samalei, Satyakrishana, CR 1014, Lunishree, Geetanjali, Ajay, Rajlaxmi Kalinga-3, and Vanaprava are having long slender grain. The varieties viz., Savitri Gayatri and Nuakalajeera are classified as short bold type. Other varieties are having medium slender grain type. The value for each character for each varieties are given in Table-2.

\subsection{Chemical Characters}

The alkali spreading value (ASV) gives the estimate of gelatinization temperature and it varied from 3.0 (Uday) to 7.0 (Indira) indicating very wide variability. The quality and quantity of starch and Gelatinization temperature strongly influence the cooking quality.The gelatinization temperature affects the water uptake, volume expansion ratio and linear kernel elongation (Vanaja \& Babu, 2003). Alkali spreading value gives an idea for gelatinization temperature.

Water uptake is very important character because it is directly related to energy consumption.It is lowest in Tapaswini (97.5) followed by Ratna (110), Kalinga-3 (115), Heera (115) and Tulsi (125) and highest in Tara (330) following Indira (302.5), Chandrama (297) and Shaktiman (197.3). More water uptake require more energy for cooking so less water uptake is good for low income consumers. The amount of water uptake during cooking process is associated with the appearance of cooked rice (Fan et al., 2000).

Kernel length after cooking (KLAC)) is highest in Geetanjali (12.5) followed by Lunishree (11.9), Supriya (11.5) and Radhi (11.1) and lowest in Pooja (6.65) following Nuakalajeera (7.9), BPT -5204 (8.1) and Nuadhusara (8.2). It is influenced by genetic factors and environment specially temperature during ripening (Dela Cruz et al., 1989). 
Table 2. Physical, chemical, cooking characters and grain yield of 41 promising rice varieties of India

\begin{tabular}{|c|c|c|c|c|c|c|c|c|c|c|c|c|c|}
\hline Varieties & Hull\% & Mill\% & HRR\% & $\mathrm{KL}(\mathrm{mm})$ & $\begin{array}{c}\mathrm{KB} \\
(\mathrm{mm})\end{array}$ & $\mathrm{L} / \mathrm{B}$ & ASV & $\mathrm{WU}(\mathrm{ml})$ & KLAC & VER & ER & $\mathrm{AC} \%$ & Yield(kg/ha) \\
\hline & & & & & upland & & & & & & & & \\
\hline Kalinga-3 & 72.5 & 64.5 & 45.5 & 6.5 & 1.9 & 3.5 & 3.25 & 115.0 & 9.55 & 3.9 & 1.46 & 24.9 & 3100 \\
\hline Vandana & 77.0 & 68.5 & 59.0 & 5.95 & 2.25 & 2.65 & 3.0 & 190.0 & 8.9 & 4.15 & 1.50 & 25.0 & 3400 \\
\hline Kalyni-2 & 76.0 & 66.5 & 43.5 & 6.6 & 2.45 & 2.7 & 3.0 & 197.5 & 10.0 & 4.0 & 1.51 & 23.7 & 3500 \\
\hline Heera & 77.0 & 80.5 & 48.5 & 6.2 & 2.35 & 2.65 & 4.0 & 115.0 & 9.5 & 3.85 & 1.5 & 25.6 & 3200 \\
\hline \multirow[t]{2}{*}{ Vanaprava } & 71.0 & 62.0 & 46.0 & 6.55 & 2.0 & 3.2 & 4.0 & 137.0 & 9.8 & 4.15 & 1.49 & 26.1 & 3300 \\
\hline & & & & & irrigated & & & & & & & & \\
\hline Kshira & 77.5 & 66.5 & 57.5 & 5.6 & 2.38 & 2.35 & 5.0 & 155 & 9.95 & 3.93 & 1.77 & 23.0 & 4500 \\
\hline Indira & 80.0 & 74.0 & 62.5 & 6.03 & 2.5 & 2.41 & 7.0 & 302.5 & 10.5 & 3.7 & 1.7 & 23.8 & 3400 \\
\hline Shaktiman & 78.5 & 71.5 & 66.0 & 5.6 & 2.3 & 2.44 & 7.0 & 297.5 & 9.5 & 3.4 & 1.66 & 24.45 & 3200 \\
\hline Radhi & 80.0 & 76.0 & 67.0 & 6.3 & 2.34 & 2.71 & 4.0 & 152.5 & 11.1 & 3.4 & 1.74 & 22.2 & 4300 \\
\hline Tara & 78.5 & 71.0 & 65.0 & 5.7 & 2.37 & 2.41 & 7.0 & 330.0 & 10.85 & 4.25 & 1.85 & 23.4 & 2800 \\
\hline Tapaswini & 80.0 & 74.0 & 64.5 & 5.45 & 2.1 & 2.2 & 4.0 & 97.5 & 9.5 & 3.57 & 1.65 & 24.45 & 5100 \\
\hline Saket-4 & 78.0 & 72.0 & 64.0 & 6.37 & 1.84 & 3.45 & 7.0 & 242.5 & 10.7 & 3.45 & 1.67 & 24.8 & 4200 \\
\hline Ratna & 79.0 & 72.5 & 58.0 & 6.5 & 1.85 & 3.46 & 5.0 & 110.0 & 10.5 & 3.4 & 1.64 & 23.1 & 4500 \\
\hline Udaya & 77.5 & 69.0 & 51.0 & 5.21 & 2.47 & 2.1 & 3.0 & 130.0 & 9.45 & 3.25 & 1.81 & 24.7 & 5100 \\
\hline Supriya & 79.0 & 74.5 & 60.5 & 6.5 & 2.29 & 2.85 & 5.0 & 125.0 & 11.5 & 4.0 & 1.76 & 22.7 & 3900 \\
\hline Naveen & 80.25 & 73.8 & 66.25 & 5.5 & 2.4 & 2.3 & 3.0 & 237.5 & 9.28 & 3.87 & 1.65 & 23.2 & 4500 \\
\hline Samalei & 78.5 & 71.0 & 64.0 & 6.67 & 2.21 & 3.01 & 6.0 & 150.0 & 10.95 & 3.75 & 1.62 & 24.7 & 4200 \\
\hline Chandan & 77.3 & 71.0 & 65.0 & 5.57 & 2.29 & 2.42 & 5.6 & 200.0 & 8.0 & 4.1 & 1.44 & 23.7 & 4700 \\
\hline Chandrama & 79.0 & 72.75 & 64.5 & 5.7 & 2.35 & 2.40 & 5.0 & 297.0 & 9.2 & 4.3 & 1.61 & 24.8 & 5400 \\
\hline \multirow[t]{2}{*}{ Satyakrishna } & 77.0 & 71.0 & 63.65 & 6.5 & 1.72 & 3.51 & 3.9 & 161.5 & 11.1 & 4.75 & 1.70 & 24.95 & 6300 \\
\hline & & & & & lowland & & & & & & & & \\
\hline CR1014 & 78.0 & 72.0 & 66.0 & 5.5 & 1.8 & 3.05 & 6.0 & 187.5 & 9.0 & 3.6 & 1.62 & 24.0 & 4100 \\
\hline Pooja & 79.0 & 71.5 & 68.0 & 5.6 & 2.65 & 2.73 & 5.0 & 202.5 & 6.65 & 3.4 & 1.71 & 22.0 & 4600 \\
\hline Padmini & 77.5 & 71.5 & 66.0 & 5.36 & 1.8 & 2.9 & 6.0 & 170.0 & 9.0 & 3.4 & 1.68 & 23.2 & 3600 \\
\hline Utkalprava & 79.5 & 70.5 & 57.5 & 5.6 & 2.01 & 2.79 & 6.0 & 165.0 & 9.5 & 3.75 & 1.68 & 22.1 & 4100 \\
\hline Lunishree & 80.0 & 72.2 & 58.0 & 7.1 & 2.24 & 3.17 & 5.5 & 165.0 & 11.9 & 4.1 & 1.67 & 24.2 & 3900 \\
\hline Panidhan & 79.0 & 68.0 & 62.0 & 5.8 & 2.08 & 2.82 & 5.5 & 170.0 & 9.3 & 4.1 & 1.59 & 23.9 & 3600 \\
\hline Gayatri & 80.0 & 71.5 & 61.0 & 4.97 & 2.7 & 1.8 & 5.0 & 185.0 & 9.0 & 4.12 & 1.81 & 24.4 & 6100 \\
\hline Tulsi & 79.0 & 70.0 & 65.0 & 5.96 & 2.21 & 2.69 & 6.0 & 125.0 & 10.4 & 4.0 & 1.74 & 23.5 & 4700 \\
\hline Durga & 80.0 & 70.0 & 62.5 & 4.92 & 2.17 & 2.51 & 5.5 & 120.0 & 9.15 & 4.0 & 1.65 & 22.8 & 4800 \\
\hline Sarala & 78.0 & 70.0 & 65.0 & 5.75 & 2.02 & 2.85 & 5.0 & 150.0 & 10.05 & 4.0 & 1.74 & 22.2 & 4400 \\
\hline Savitri & 79.0 & 68.5 & 58.5 & 5.0 & 2.57 & 1.94 & 6.0 & 165.0 & 8.6 & 3.87 & 1.72 & 24.3 & 5600 \\
\hline Varsadhan & 77.5 & 70.0 & 62.0 & 6.0 & 2.34 & 2.57 & 4.0 & 200.0 & 10.75 & 4.67 & 1.75 & 24.3 & 6200 \\
\hline \multirow[t]{2}{*}{ Hanseswari } & 79.3 & 69.3 & 46.0 & 5.42 & 2.68 & 2.25 & 5.1 & 155.0 & 8.4 & 3.62 & 1.52 & 23.9 & 4200 \\
\hline & & & & & Scented & & & & & & & & \\
\hline Geetanjali & 80.0 & 71.5 & 54.2 & 7.54 & 1.88 & 3.97 & 5.0 & 215 & 12.5 & 4.12 & 1.66 & 24.5 & 4200 \\
\hline Ketekijoha & 79.75 & 74.0 & 64.0 & 5.47 & 1.91 & 2.87 & 4.0 & 220.0 & 9.12 & 4.0 & 1.57 & 22.4 & 3900 \\
\hline Nuakalajeera & 74.5 & 67.5 & 60.5 & 3.92 & 2.1 & 1.85 & 4.6 & 183.6 & 7.9 & 5.25 & 2.0 & 22.35 & 4300 \\
\hline \multirow[t]{2}{*}{ Nuadhusara } & 77.5 & 67.4 & 66.1 & 3.88 & 1.83 & 2.11 & 5.0 & 227.5 & 8.2 & 5.15 & 2.07 & 22.05 & 4800 \\
\hline & & & & & hybrids & & & & & & & & \\
\hline Ajay & 81.0 & 72.5 & 63.0 & 7.25 & 2.07 & 3.5 & 4.35 & 217.5 & 10.55 & 3.82 & 1.47 & 24.8 & 6400 \\
\hline \multirow[t]{2}{*}{ Rajlaxmi } & 79.0 & 71.0 & 60.6 & 7.45 & 1.94 & 3.84 & 5.0 & 250.0 & 10.3 & 3.92 & 1.47 & 24.05 & 7100 \\
\hline & & & & & quality & & & & & & & & \\
\hline Lalat & 80.0 & 71.8 & 62.0 & 6.5 & 2.05 & 3.15 & 3.04 & 132.5 & 10.5 & 4.15 & 1.65 & 23.15 & 4600 \\
\hline BPT5204(ck) & 79.5 & 74.0 & 57.5 & 5.4 & 1.85 & 2.91 & 4.0 & 230.0 & 8.1 & 4.0 & 1.55 & 23.6 & 5100 \\
\hline Mean & 78.3 & 70.9 & 60.1 & 5.85 & 2.16 & 2.76 & 4.88 & 185.4 & 9.78 & 3.95 & 1.66 & 23.8 & 4460.9 \\
\hline $\mathrm{CV}(\%)$ & 1.26 & 4.57 & 3.73 & 2.26 & 2.21 & 3.29 & 2.78 & 10.1 & 2.03 & 6.97 & 2.16 & 2.25 & 3.61 \\
\hline $\mathrm{SEm}_{-}+$ & 0.70 & 2.29 & 1.58 & 0.09 & 0.03 & 0.06 & 0.09 & 13.24 & 0.14 & 0.19 & 0.02 & 0.38 & 112.67 \\
\hline $\mathrm{CD}(5 \%)$ & 2.0 & 6.55 & 4.5 & 0.26 & 0.09 & 0.18 & 0.27 & 37.85 & 0.40 & 0.55 & 0.07 & 1.08 & 326.04 \\
\hline
\end{tabular}

Note: Hull\%: Hulling \%; Mill\%: Milling \%; HRR\%: Head rice recovery \%; KL: Kernel length; KB: Kernel breadth; ASV: Alkali spreading value; WU: Water uptake; KLAC: Kernel length after cooking; ER: Elongation ratio; VER: Volume expansion ratio; AC: Amylose content. 


\subsection{Cooking Characters}

Elongation ratio is an important parameter for cooked rice. If rice elongates length wise, it gives finer appearance and it expands girth wise, it gives coarse look. Elongation ratio of the tested genotypes is highest in Nuadhusara (2.07) and Nuakalajeera (2.0) followed by Tara (1.85), Uday (1.81), Gayatri (1.81) and lowest in Chandan (1.44), Ajay (1.47) and Rajlaxmi (1.47). Aromatic short grain rice are having highest elongation ratio and hybrids are having lowest elongation ratio.

Volume expansion ratio is highest in Nua kalajeera (5.25), Nuadhusara (5.15) and lowest in Udaya (3.25). Out of 41 varieties, 21 varieties are having ideal value for volume expansion ratio (4.0-5.0). It is the positive character for lower income group for whom quantity is important criteria. However, more will be volume expansion ratio, less will be energy content per unit volume.

Amylose content is the major factor for eating quality (Juliano, 1993). It determines the hardness or stickiness of cooked rice, cohesiveness, tenderness, colour of cooked rice. Higher amylase content $(>25.0 \%)$ gives non sticky soft or hard cooked rice. Rice varieties having $20-25 \%$ amylase content gives soft and flaky cooked rice. It is an indicator of volume expansion and water absorption during cooking (Deyner et al., 2001). Intermediate amylose content (20-25\%) is usually preferred by Indians. In this study, all the tested genotypes are having intermediate amylose content except Heera (25.6) and Vanaprava (26.1).

Besides quality, yield is also very important for the farmers. Yield is highest in Rajlaxmi $\left(7100 \mathrm{~kg} \mathrm{ha}^{-1}\right)$ followed by Ajay $\left(6400 \mathrm{~kg} \mathrm{ha}^{-1}\right)$, Satyakrishna $\left(6300 \mathrm{~kg} \mathrm{ha}^{-1}\right)$,Varshadhan $\left(6200 \mathrm{~kg} \mathrm{ha}^{-1}\right)$ and Gayatri $\left(6100 \mathrm{~kg} \mathrm{ha}^{-1}\right)$ and lowest in Tara $\left(2800 \mathrm{~kg} \mathrm{ha}^{-1}\right)$ following Kalinga-3 (3100 kg ha $\left.{ }^{-1}\right)$ and Shaktiman $\left(3200 \mathrm{~kg} \mathrm{ha}^{-1}\right)$.

The best genotypes for different characters are given in Table 3. The hybrids Ajay and Rajlaxmi possess high yield, head rice recovery, kernel length, kernel length after cooking. The varieties viz., Nuakalajeera and Nuadhusara possess high head rice recovery, kernel breadth and elongation ratio. Satyakrishna, a double haploid variety is very good in yield, head rice recovery, kernel length and kernel length after cooking and low kernel breadth. Geetanjali possess high Kernel length, Kernel length after cooking and low kernel breadth. Varshadhan possess high HRR\%, Kernel length after cooking and yield. Ketekijoha and Tapaswini are having high HRR\% which is very important character for making more profit. The varieties viz. Ajaya, Rajlaxmi, Varshadhan and Geetanjali are having good quality characters and yield better than check. So these varieties may be used in varietal development programme and popularized among the farmers.

Table 3. Promising rice genotypes for different characters

\begin{tabular}{|c|c|c|}
\hline Characters & & Name of varieties \\
\hline Hulling (\%) & $>80$ & Indira, Radhi, Tapaswini, Naveen, Lunishree, Gayatri, Durga, Geetanjali, Lalat, Ajaya \\
\hline Milling (\%) & $>74$ & Indira, Radhi, Tapaswini, Supriya, Ketekijoha, BPT5204 \\
\hline $\operatorname{HRR}(\%)$ & $>65$ & $\begin{array}{l}\text { Nuadhusara, Sarala, Tulsi, Padmini, Radhi, Tara, Naveen, } \\
\text { Chandan, CR1014, Pooja, Shaktiman }\end{array}$ \\
\hline $\mathrm{KL}(\mathrm{mm})$ & $>6.5$ & $\begin{array}{l}\text { Kalinga-3, Vanaprava, Kalyani-2, Ratna, Samalei, Satyakrishna, Lunishree, Geetanjali, Lalat, } \\
\text { Ajaya, Rajlaxmi }\end{array}$ \\
\hline $\mathrm{KB}(\mathrm{mm})$ & $<2.0$ & $\begin{array}{l}\text { Kalinga-3, Saket-4, Ratna, Satyakrishna, CR1014, Padmini, Geetanjali, Ketekijoha, } \\
\text { Nuadhusara, BPT5204, Vanaprava, Rajlaxmi }\end{array}$ \\
\hline L./B ratio & $>3.0$ & $\begin{array}{l}\text { Kalinga-3, Vanaprava, Samalei, Satyakrishna, CR-1014, Lunishree, Ajaya, Rajlaxmi, Geetanjali, } \\
\text { Lalat, Ratna, Saket-4 }\end{array}$ \\
\hline ASV & $4.0-5.0$ & $\begin{array}{l}\text { Heera, Ratna, Chandrama, Pooja, Gayatri, Sarala, Varshadhan, Geetanjali, Ajaya, Rajlaxmi, } \\
\text { Nuadhusara. }\end{array}$ \\
\hline KLAC & $>10.5$ & $\begin{array}{l}\text { Indira, Radhi, Tara, Saket-4, Ratna, Supriya, Samalei, Satyakrishna, Lunishree, } \\
\text { Varshadhan, Geetanjali, Lalat, Ajaya }\end{array}$ \\
\hline ER & $>1.8$ & Nuakalajeera, Nuadhusara, Tara, Udaya, Gayatri \\
\hline $\begin{array}{l}\text { Yield } \\
(\mathrm{kg} / \mathrm{ha})\end{array}$ & $>6000$ & Satyakrishna, Gayatri, Vashadhan, Ajaya, Rajlaxmi \\
\hline
\end{tabular}

Note: Hull\%: Hulling \%; Mill\%: Milling \%; HRR\%: Head rice recovery \%; KL: Kernel length; KB: Kernel breadth; ASV: Alkali spreading value; WU: Water uptake; KLAC: Kernel length after cooking; ER: Elongation ratio; VER: Volume expansion ratio; AC: Amylose content. 


\section{Reference}

Anonymous. (2002). National workshops on Rice Research and Extension 2002. Feeding the extra millions by 2025 (p. 1). Bangladesh Rice Research Institutes, Gazipur.

Anonymous. (2004). Laboratory manual on rice grain quality procedures. Directotate of Rice Research (pp. 1-20). Rajendranagar, Hyderabad, India.

Asish, K., Binod, R., Kalaiyarasi K., Thiyagarajan, \& Manonmani, S. (2006). Physio-chemical and cooking quality characteristics of promising varieties and hybrids in rice (Oryza sativa L.). Ind. Journal Genet, 66(2), 107-112.

Azeez, M. H., \& Shafi, M. (1966). Quality in rice. Technical Bulletin 13 (p. 50). Department of Agriculture, Government of West Pakistan, Lahore.

Beachell, H. M., \& Stansel, J. W. (1963). Selecting rice for specific cooking characteristics in a breeding programme. Int. Rice. Comm. Newsl, (Special issue), 25-40.

Bhonsle, S. J., \& Sellapan, K. (2010). Grain quality evaluation of traditionally cultivated rice varieties of Goa, India. Recent Research in Science and Technology, 2(6), 88-97.

Das Sangeeta, \& Borah, S. P. (2008). Studies on the genetic component of varieties for yield attributing and quality characters of some traditional rice varieties of Nalbari districts of Assam. Indian J. Crop Sciences, 3, 103-106.

Dela Cruz, N., Kumar, I., Kausik, R. P., \& Khush, G. S. (1989). Effect of temperature during grain development on the performance and stability of cooking quality component of rice. Japaneese Journal of breeding, 39, 299-306.

Deyner, K., Johnson, P., Zeeman, S., \& Smith, A. M. (2001). The control of amylase synthesis. Journal of Plant physiology, 158, 479-487. http://dx.doi.org/10.1078/0176-1617-00360

Fan, J., Seibenmorgan, T. J., \& Yang, W. (2000). A study of head rice yield reduction of long and medium grain varieties in relation to various harvest and drying conditions. Transactions of the American Society of Agricultural Engineers, 43, 1709-14.

Gomez, K. A., \& Gomez, A. A. (1984). Statistical Procedure for Agricultural Research. New York: John Wiley and Sons.

IRRI. (1996). Standard Evaluation Systems for rice (4th ed). INGER Genetic Resources Centre. IRRI, Manila, Philippines.

Itani, T. T., Masahiks, A. E., \& Toshroh, H. (2002). Distribution of amylase, nitrogen and minerals in rice kernel with various characteristics. Journ.Agril. Food Chem., 50, 5326-5322. http://dx.doi.org/10.1021/jf020073x

Jennings, P. R., Coffman, W. R., \& Kauffman, H. E. (1979). Grain quality (pp. 101-120), International Rice Improvement. International Rice Research Institute, Manila, Philippines.

Juliano, B. O. (1971). A simplified assay for milled rice amylose. Cereal Science Today, 16, 334-338, 340-360.

Juliano, B. O., \& Villareal, C. P. (1993). Grain quality evaluation of world rices. International Rice Research Institute, Manila, Philippines.

Juliano, B. O., Perez, C. M., \& Kaosa, M. (1990). Grain quality characteristics of export rice in selected markers. Cereal Chemistry, 67, 192-197.

Little, R. R., Hilder, G. B., \& Dawson, E. H. (1958). Differential effect of dilute alkali on 25 varieties of milled white rice. Cereal Chem., 35, 111-126.

Merca, F. E., \& Juliano, B. O., (1981). Physico-chemical properties of starch of intermediate amylase and starch. Satarke, 33, 253-260. http://dx.doi.org/10.1002/star.19810330802

Mitra, J., Pattanayak, A., Dhiman, K. R., Bhadan, V. P., Hore, D. K., \& Ngachan, S. V. (2010). Grain and food quality traits of some indigenous medicinal rice cultivars of Manipur. International journal of food properties, 13(6), 1244-1255. http://dx.doi.org/10.1080/10942910903034833

Ramiah, K. (1969). Grain classification (p. 629). In Rice Research in India, ICAR Publication.

SobhaRani, N., SubbaRao, L. V., Pandey, M. K., Sudharshan, I., \& Prasad, G. S. V. (2008). Grain quality variation for physico-chemical, milling and cooking properties in Indian rice (O. sativa L.). Indian J. Crop Sciences, 3(1), 133-136. 
Srivastava, K., Das, A., Pande, K., \& Sharma, S. G. (2012). Physico-chemical and cooking quality characteristics of some (Oryza sativa L.) genotypes from Faizabad. Indian, Journ. Agric. Biochem., 25(1), 68-70.

Tyagi, A. K., Khuran, J. P., Khurana, A. P., Raghubanshi, S., Gour, A., Kapur, A., ... Sharma, S. (2004). Structural and functional analysis of rice genome. J. Genet, $83, \quad 79-99$. http://dx.doi.org/10.1007/BF02715832

Vanaja, T., \& Babu, L. C. (2003). Association between physico-chemical characters and cooking qualities in high yielding rice varieties of diverse origin. International rice research notes, 28(1), 28-29.

Vanaja, T., \& Babu, L. C. (2006). Variability in grain quality attributes of high yielding varieties (Oryza sativa L.) of diverse origin. Jour. Trop. Agril., 44(1-2), 61-63. 